\title{
IMPLEMENTASI PERATURAN GUBERNUR NO. 34 TAHUN 2010 TENTANG URAIAN TUGAS DAN FUNGSI UNIT PELAKSANA TEKNIS DINAS PENGELOLAAN KEUANGAN DAN ASET DAERAH KABUPATEN SERANG
}

\author{
Suharyono \\ Sekolah Tinggi Ilmu Administrasi Maulana Yusuf Banten
}

Email: Suharyono123@gmail.com

\begin{abstract}
Implementation Governor Rules Number 34 Year 2010 a bout on the Description of Duties and Functions of the Regional Technical Implementation Unit in the Region of Banten Province in Technical Implementation Unit of the Department of Management of Regional Assets and Assets of Serang regency Suharyono, Regional autonomy provides local authorities to make the norm of about regional organizations. Peraturan Gubernur No. 34 Tahun 2010 on Duties and Functions of the Office of Technical Implementation Unit Banten Provincial structured as public policies that govern the work system UPT UPT organization in order to run effectively. The purpose of this study was to analyze the impact of public policy on the effectiveness of the organization at the Technical Implementation Unit Office of Financial Management and Asset Serang District. This research is using qualitative approach. The object of this research is the UPT Office of Financial Management and Asset Serang district, Banten Province. Based on the interview with the Head Unit, Head of Sub Division of Administration, staff and staff PKB and BBNKB Other revenues can be concluded that the public policy that t Peraturan Gubernur No. 34 Tahun 2010 on Duties and Functions of the Office of Technical Implementation Unit Banten Provincial UPT has been run by the Department of Finance and Asset Management Serang regency well. Order Unit Office of Financial Management and Asset Serang regency in implementing public policies impact on the ongoing activities of organiasi effectively.
\end{abstract}

Keywords: Public Policy, Implementation

\section{PENDAHULUAN}

Indonesia merupakan negara kesatuan dengan bentuk pemerintahan Republik yang terdiri atas 34 provinsi. Pemerintahan di Indonesia terbagi menjadi dua yakni pemerintah pusat dan pemerintah daerah. Setiap provinsi di Indonesia dipimpin oleh Gubernur dan termasuk dalam sistem pemerintahan daerah. Setiap pemerintah daerah provinsi memiliki kewenangan dalam menetapkan kebijakan sesuai dengan kondisi dan kebutuhan provinsi masing-masing daerah akan tetapi tidak bertentangan dengan peraturan pemerintah pusat.

Kewenangan pemerintah daerah untuk mengatur daerahnya sendiri merupakan implentasi dari kebijakan otonomi daerah yang berdasarkan pada Undang-Undang (UU) Nomor 22 Tahun 1999 tentang Pemerintahan Daerah yang kemudian disempurnakan dengan UU No 32 tahun 2004 tentang Pemerintahan Daerah. Otonomi daerah menurut pasal 1 ayat (5) UU No 32 tahun 2004 tentang Pemerintahan Daerah adalah hak, wewenang, dan kewajiban daerah otonom untuk mengatur dan mengurus sendiri urusan pemerintahan dan kepentingan masyarakat setempat sesuai dengan peraturan perundang-undangan.

Otonomi daerah memberikan kewenangan pemerintah daerah untuk membuat peratuan tentang organisasi daerah. Contoh kebijakan yang dibuat oleh pemerintah daerah mengenai organisasi daerah adalah Peraturan Daerah Provinsi Banten Nomor 3 Tahun 2008

Implementasi Peraturan Gubernur No. 34 Tahun 2010 Tentang Uraian Tugas dan Fungsi Unit Pelaksana Teknis Dinas Pengelolaan Keuangan dan Aset Daerah 
tentang Pembentukan, Organisasi dan Tata Kerja Dinas Daerah Provinsi Banten. Peraturan Daerah Provinsi Banten Nomor 3 Tahun 2008 tentang Pembentukan, Organisasi dan Tata Kerja Dinas Daerah Provinsi Banten mengatur tentang kewenangan pemerintah daerah untuk membentuk dinas-dinas dalam rangka membantu penyelenggaraan pemerintahan daerah, dimana Gubernur perlu dibantu oleh perangkat daerah yang dapat menyelenggarakan seluruh urusan pemerintahan yang dilaksanakan oleh pemerintahan daerah.

Salah satu dinas yang diperlukan di setiap daerah adalah Dinas Pengelolaan Keuangan dan Aset Daerah Kabupaten Serang. Dinas Pengelolaan Keuangan Dan Aset Daerah merupakan unsur pelaksana otonomi daerah di bidang pengelolaan keuangan dan aset daerah (Peraturan Daerah Provinsi Banten Nomor 3 Tahun 2008 pasal 24 ayat (1)). Dalam pelaksanaan tugasnya, Dinas Pengelolaan Keuangan dan Aset Daerah Kabupaten Serang dibantu oleh Unit Pelaksana Teknis. Uraian tugas, wewenangan, tanggung jawab dan tata kerja Unit Pelaksana Teknis Dinas Pengelolaan Keuangan dan Aset Daerah Kabupaten Serang diatur lebih lanjut pada Peraturan Gubernur No. 34 Tahun 2010 tentang Uraian Tugas dan Fungsi Unit Pelaksana Teknis Dinas pada Daerah Provinsi Banten.

Pentingnya sebuah struktur organisasi akan membantu manajer dari hasil keputusan dalam mendesain organisasi sebagai cara mengidentifikasi dari pengelolaan sumber daya manusia dan segala fungsi-fungsi yang ada untuk penyelesaian pekerjaan perusahaan dengan pedoman visi, misi dan tujuan organisasi (Gammahendra dkk, 2014:3). Peraturan Gubernur No. 34 Tahun 2010 tentang Uraian Tugas dan Fungsi Unit Pelaksana Teknis Dinas pada Daerah Provinsi Banten mengatur bagaimana setiap bagian dalam UPT menjalankan tanggung jawab dan cara tata kerjanya. Pembagian departemen dan tanggungjawab dilakukan oleh manajemen dalam rangka agar setiap departemen melaksanakan pekerjaannya dengan baik.
Susunan organisasi dan struktur organisasi disusun dalam satu garis komando dengan tujuan untuk mencapaian visi, misi dan tujuan perusahaan. Dalam hal ini pencapaian tujuan Unit Pelaksana Teknis Dinas Pengelolaan Keuangan dan Aset Daerah Kabupaten Serang. Gammahendra dkk (2014:2) menjelaskan bahwa struktur organisasi didesain dengan baik untuk sebuah organisasi yang efektif yang mana dengan adanya sumber daya manusia dalam organisasi perusahaan struktur organisasi dapat diimplementasikan sesuai sistem kerja organisasi untuk tujuan organisasi yang efektif dan efisien. Dapat disimpulkan bahwa Peraturan Gubernur No. 34 Tahun 2010 tentang Uraian Tugas dan Fungsi Unit Pelaksana Teknis Dinas pada Daerah Provinsi Banten disusun sebagai kebijakan publik yang mengatur sistem kerja UPT dengan tujuan agar organisasi UPT dapat berjalan efektif.

Gammahendra dkk (2014:2) menjelaskan bahwa ditinjau dari segi-segi efektivitas organisasi terjadi karena dipengaruhi oleh aspek struktur organisasi yang memiliki persamaan dan hubungan dalam pencapaian tujuan. Proses pencapaian tujuan yang bagus berarti adanya konsistensi dan fokus dalam upaya pemimpin yang mengintegrasikan visi dan misi kepada pegawai, dengan timbal balik pegawai berkinerja baik secara konsisten dan fokus sesuai sistem yang telah dirancang bagi kelangsungan hidup organisasi. Akan tetapi dalam pelaksanaan peraturan tersebut, sering terjadi permasalahan. Salah satunya adalah terdapat anggota organisasi yang melanggar pedoman pelaksanaan tata kerja tersebut sehingga bisa berdampak pada tidak berjalannya organisasi secara efektif dan mengganggu aktivitas di dalam organiasi tersebut. Oleh karena itu, penulis tertarik untuk meneliti Implementasi Peraturan Gubernur No.34 Tahun 2010 Tentang Tugas Dan Fungsi Unit Pelaksana Teknis Daerah Pada Daerah Provinsi Banten Di Unit Pelaksana Teknis Dinas Pengelolaan Keuangan dan Aset Daerah Kabupaten Serang. 
Chandler dan Plano ( 1988 ) dalam Tangkilisan (2003:1), Kebijakan publik adalah pemanfaatan yang strategis terhadap sumberdaya-sumberdaya yang ada untuk memecahkan masalah-masalah publik atau pemerintah. Kebijakan publik merupakan suatu bentuk intervensi yang dilakukan secara terus menerus oleh pemerintah demi kepentingan kelompok yang kurang beruntung dalam masyarakat agar mereka dapat hidup, dan ikut berpartisipasi dalam pembangunan secara luas. Sehingga dapat disimpulkan bahwa kebijakan publik adalah kebijakan yang dibuat pemerintah dalam rangka pemecahan masalah publik.

Peraturan Daerah Provinsi Banten Nomor 3 Tahun 2008 tentang Pembentukan, Organisasi dan Tata Kerja Dinas Daerah Provinsi Banten mengatur tentang kewenangan pemerintah daerah untuk membentuk dinasdinas dalam rangka membantu penyelenggaraan pemerintahan daerah, dimana Gubernur perlu dibantu oleh perangkat daerah yang dapat menyelenggarakan seluruh urusan pemerintahan yang dilaksanakan oleh pemerintahan daerah. Dinas Pengelolaan Keuangan Dan Aset Daerah merupakan unsur pelaksana otonomi daerah di bidang pengelolaan keuangan dan aset daerah (Peraturan Daerah Provinsi Banten Nomor 3 Tahun 2008 pasal 24 ayat (1)). Dinas Pengelolaan Keuangan dan Aset Daerah mempunyai tugas pokok melaksanakan urusan pemerintahan daerah berdasarkan asas otonomi daerah dan tugas pembantuan di bidang pengelolaan keuangan dan aset daerah (Peraturan Daerah Provinsi Banten Nomor 3 Tahun 2008 pasal 25).

Edward III dalam Agustino (2016:136-141) mengemukakan teori implementasi kebijakan yang berperspektif top-down dikembangkan oleh George menamakan model implementasi kebijakan publiknya dengan istilah Direct and Indirect Impact on Implementation. Dalam pendekatan yang diteoremakan oleh Edward III, terdapat empat variabel yang sangat menentukan keberhasilan implementasi suatu kebijakan, yaitu: (i) komunikasi; (ii) sumber daya; (iii) disposisi; dan (iv) struktur birokrasi.

Variabel pertama yang mempengaruhi keberhasilan implementasi suatu kebijakan, menurut Edward III, adalah komunikasi, menurutnya, sangat menentukan keberhasilan pencapaian tujuan dari implementasi kebijakan publik. Implementasi yang efektif terjadi apabila para pembuat keputusan sudah mengetahui apa yang akan mereka kerjakan. Pengetahuan atas apa yang akan mereka kerjakan dapat berjalan bila komunikasi berjalan dengan baik sehingga setiap keputusan kebijakan dan peraturan implementasi harus ditransmisikan (atau dikomunikasikan) kepada bagian personalia yang tepat. Selain itu, kebijakan yang dikomunikasikan pun harus tepat, akurat, dan konsisten. Komunikasi (atau pentransmisian informasi) diperlukan agar para pembuat keputusan di dan para implementor akan semakin konsisten dalam melaksanakan setiap kebijakan yang akan diterapkan dalam masyarakat

Variabel pertama yang mempengaruhi keberhasilan implementasi suatu kebijakan, menurut Edward III, adalah komunikasi. Komunikasi, menurutnya, sangat menentukan keberhasilan pencapaian tujuan dari implementasi kebijakan publik. Implementasi yang efektif terjadi apabila para pembuat keputusan sudah mengetahui apa yang akan mereka kerjakan. Pengetahuan atas apa yang akan mereka kerjakan dapat berjalan bila komunikasi berjalan dengan baik sehingga setiap keputusan kebijakan dan peraturan implementasi harus ditransmisikan (atau dikomunikasikan) kepada bagian personalia yang tepat. Selain itu, kebijakan yang dikomunikasikan pun harus tepat, akurat, dan konsisten. Komunikasi (atau pentransmisian informasi) diperlukan agar para pembuat keputusan di dan para implementor akan semakin konsisten dalam melaksanakan setiap kebijakan yang akan diterapkan dalam masyarakat.

Variabel kedua yang mempengaruhi keberhasilan implementasi suatu kebijakan adalah sumber daya. Apadun indikator sumber- 
sumber daya terdiri dari beberapa elemen, yaitu:

a. Staf; sumber daya utama dalam implementasi kebijakan adalah staf atau sumber daya manusia (SDM). Kegagalan yang sering terjadi dalam implementasi kebijakan salah satunya disebabkan oleh karena staf yang tidak mencukupi, memadai, ataupun tidak kompeten di bidangnya. Penambahan jumlah staf atau implementor saja tidak mencukupi, tetapi diperlukan pula kecukupan staf dengan keahlian serta kemampuan yang diperlukan (kompeten dan kapabilitas) dalam mengimplementasikan kebijakan atau melaksanakan tugas yang diinginkan oleh kebijakan itu sendiri.

b. Informasi; dalam implementasi kebijakan, informasi mempunyai dua bentuk yaitu: (i) informasi yang berhubungan dengan cara melaksanakan kebijakan. Implementor harus mengetahui apa yang harus mereka lakukan di saat mereka diberi perintah untuk melakukan tindakan. Dan (ii) informasi mengenai data kepatuhan dari para pelaksana terhadap peraturan dan regulasi pemerintah yang telah ditetapkan. Implementor harus mengetahui apakah orang lain yang terlibat di dalam pelaksanaan kebijakan tersebut patuh terhadap hukum.

c. Wewenang; pada umumnya kewenangan harus bersifat formal agar perintah dapat dilaksanakan. Kewenangan merupakan otoritas atau legitimasi bagi para pelaksana dalam-melaksanakan kebijakan yang ditetapkan secara politik. Ketika wewenang itu nihil, maka kekuatan para implementor di mata publik tidak terlegitimasi, sehingga dapat menggagalkan proses implementasi kebijakan. Tetapi, dalam konteks yang lain, ketika wewenang formal tersebut ada, maka sering terjadi kesalahan dalam melihat efektivitas kewenangan. Di satu pihak, efektivitas kewenangan diperlukan dalam pelaksanaan implementasi kebijakan; tetapi di sisi lain, efektifitas akan menyurut manakala wewenang diselewengkan oleh para pelaksana demi kepentingannya sendiri atau demi kepentingan kelompoknya.

d. Fasilitas; fasilitas fisik juga merupakan faktor penting dalam implementasi kebijakan. lmplementor mungkin memiliki staf yang mencukupi, mengerti apa yang harus dilakukannya, dan memiliki wewenang untuk melaksanakan tugasnya, tetapi tanpa adanya fasilitas pendukung (sarana dan prasarana) maka implementasi kebijakan tersebut tidak akan berhasil.

Variabel ketiga yang mempengaruhi tingkat keberhasilan implementasi kebijakan publik, adalah disposisi. Disposisi atau 'sikap dari pelaksana kebijakan' adalah faktor penting ketiga dalam pendekatan mengenai pelaksanaan suatu kebijakan publik. Jika pelaksanaan suatu kebijakan ingin efektif, maka para pelaksana kebijakan tidak hanya harus mengetahui apa yang akan dilakukan tetapi juga harus memiliki kemampuan untuk melaksanakannya, sehingga dalam praktiknya tidak terjadi bias.

Hal-hal penting yang perlu dicermati pada variabel disposisi, menurut Edward III, adalah:

a. Efek Disposisi; disposisi atau sikap para pelaksana akan menimbulkan hambatanhambatan yang nyata terhadap implementasi kebijakan bila personil yang ada tidak melaksanakan kebijakankebijakan yang diinginkan oleh pejabatpejabat tinggi. Oleh karena itu, pemilihan dan pengangkatan personil pelaksana kebijakan haruslah orang-orang yang memiliki dedikasi pada kebijakan yang telah ditetapkan; lebih khusus lagi pada kepentingan warga.

b. Melakukan Pengaturan Birokrasi (stffing the bureaucracy); dalam konteks ini Edward III mensyaratkan bahwa implementasi kebijakan harus dilihat juga dalam hal pengaturan birokrasi. Ini merujuk pada penunjukan dan pengangkatan staf dalam birokrasi yang sesuai dengan kemampuan, kapabilitas, dan kompetensinya. Selain itu, pengaturan birokrasi juga bermuara pada 
'pembentukan' sistem pelayanan publik yang optimal, penilaian personil dalam bekerja, hingga metode bypassing personil

c. Insentif; Edward III menyatakan bahwa salah satu teknik yang disarankan untuk mengatasi masalah kecenderungan para pelaksana adalah dengan memanipulasi insentif. Pada umumnya orang bertindak menurut kepentingan mereka sendiri, maka memanipulasi insentif oleh para pembuat kebijakan mempengaruhi tindakan para pelaksana kebijakan. Dengan cara menambah keuntungan atau biaya tertentu mungkin akan menjadi faktor pendorong yang membuat para pelaksana kebijakan melaksanakan perintah dengan baik. Hal ini dilakukan sebagai upaya memenuhi kepentingan pribadi (self interest) atau organisasi.

Variabel keempat, struktur birokrasi, walaupun sumber-sumber daya untuk melaksanakan suatu kebijakan tersedia, atau para pelaksana kebijakan mengetahui apa yang seharusnya dilakukan, dan mempunyai keinginan untuk melaksanakan suatu kebijakan, kemungkinan kebijakan tersebut tidak dapat terlaksana atau terealisasi karena terdapat kelemahan dalam struktur birokrasi. Kebijakan yang begitu kompleks menuntut adanya kerjasama banyak orang, ketika struktur birokrasi tidak kondusif pada kebijakan yang tersedia, maka hal ini akan menyebabkan sumber-sumber daya menjadi tidak efektif dan tidak termotivasi sehingga menghambat jalannya kebijakan. Birokrasi sebagai pelaksana sebuah kebijakan harus dapat mendukung kebijakan yang telah diputuskan secara politik dengan jalan melakukan koordinasi dengan baik.

Dua karakteristik, menurut Edward III, yang dapat mendongkrak kinerja struktur birokrasi atau organisasi ke arah yang lebih baik adalah:

a. Membuat Standar Operating Procedures (SOPs) yang lebih fleksibel; SOPs adalah suatu prosedur atau aktivitas terencana rutin yang memungkinkan para pegawai (atau pelaksana kebijakan seperti aparatur, administratur, atau birokrat) untuk melaksanakan kegiatan-kegiatannya pada setiap harinya (days-todays politics) sesuai dengan standar yang telah ditetapkan (atau standar minimum yang dibutuhkan warga).

b. Melaksanakan fragmentasi, tujuannya untuk menyebar tanggungjawab pelbagai aktivitas, kegiatan, atau program pada beberapa unit kerja yang sesuai dengan bidangnya masing-masing. Dengan terfragmentasinya struktur birokrasi, maka implementasi akan lebih efektif karena dilaksanakan oleh organisasi yang kompeten dan kapabel.

Peraturan Gubernur No. 34 Tahun 2010 tentang Uraian Tugas dan Fungsi Unit Pelaksana Teknis Dinas pada Daerah Provinsi Banten mengatur bagaimana uraian tugas, wewenangan, tanggung jawab dan tata kerja setiap bagian dalam UPT. Dalam Pergub tersebut dijabarkan secara lengkap tugas dan fungsi kepala unit UPT, Sub Bagian Tata Usaha, Seksi PKB dan BBNKB, dan Seksi Pendapatan Lain-lain.

Permasalahan dalam penelitian ini adalah bagaimana Implemantasi Pergub No. 34 tentang Uraian Tugas dan Fungsi Unit Pelaksana Teknis Pada Unit Pelaksana Teknis Daerah pad Daerah Provinsi Banten di Unit Pelaksana Teknis Dinas Pengelolaan Keuangan dan Aset Daerah Kabupaten Serang

Tujuan penelitian ini adalah untuk mengetahui Implemantasi Pergub No. 34 tentang Uraian Tugas dan Fungsi Unit Pelaksana Teknis Pada Unit Pelaksana Teknis Daerah pad Daerah Provinsi Banten di Unit Pelaksana Teknis Dinas Pengelolaan Keuangan dan Aset Daerah Kabupaten Serang.

\section{METODE PENELITIAN}

Penelitian ini merupakan penelitian dengan menggunakan pendekatan kualitatif. Teknik pentuan informan menggunakan purposive sampling yaitu pegawai UPT Dinas Pengelolaan Keuangan dan Aset Daerah Kabupaten Serang, Provinsi Banten. Data yang digunakan dalam penelitian ini adalah data primer dan data sekunder. Teknik pengumpulan 
data yang digunakan dalam penelitian ini adalah observasi, wawancara, dan dokumentasi. Teknik analisis data yang digunakan dalam penelitian ini adalah analisis data model Miles dan Huberman yang terdiri atas reduksi data, display/penyajian data, dan kesimpulan/verifikasi.

\section{HASIL DAN PEMBAHASAN}

Pada tahapan ini akan dilakukan analisis data dari penelitian yang telah dilakukan dan telah disajikan di atas. Berikut peneliti akan memaparkan analisis dari data

Sistem yang dirancang dalam organisasi UPT Dinas Pengelolaan Keuangan dan Aset Daerah Kabupaten Serang berdasarkan pada Peraturan Gubernur No. 34 Tahun 2010 tentang Uraian Tugas dan Fungsi Unit Pelaksana Teknis Dinas pada Daerah Provinsi Banten yang mengatur bagaimana uraian tugas, wewenangan, tanggung jawab dan tata kerja setiap bagian dalam UPT. Dalam Pergub tersebut dijabarkan secara lengkap tugas dan fungsi kepala unit UPT, Sub Bagian Tata Usaha, Seksi PKB dan BBNKB, dan Seksi Pendapatan Lain-lain.

Kepala Unit merupakan kepala yang bertanggungjawab memimpin semua kegiatan yang berlangsung di UPT Dinas Pengelolaan Keuangan dan Aset Daerah Kabupaten Serang. Uraian tugas dan wewenang kepala unit diatur dalam Peraturan Gubernur Banten No. 34 Tahun 2010 pasal 3 ayat (1) dan (2). Berdasarkan pasal 3 ayat (1), Kepala Unit mempunyai tugas membantu Kepala Dinas dalam melaksanakan urusan pemerintahan di bidang teknis operasional pengelolaan keuangan dan aset daerah. Sedangkan dalam pasal 3 ayat (2) dijelaskan Kepala Unit mempunyai fungsi :

a. penyusunanrencana teknis operasional dibidang pengelolaan dan pelayanan pajak Provinsi;

b. pelaksanaan kebijakan teknis operasional dibidang pengelolaan dan pelayanan pajak Provinsi;

c. pelaksanaan pendaftaran, penetapan dan penagihan pajak provinsi; d. pelaksanaan pembukuan dan pelaporan;

e. pelaksanaan urusan ketatausahaan;

f. pelaksanaan tugas lain yang diberikan Kepala Dinas sesuai dengan tugas dan fungsinya.

Dalam pelaksanaannya, Kepala Unit UPT Dinas Pengelolaan Keuangan dan Aset Daerah Kabupaten Serang melaksanakan tugas dan wewenanganya dengan baik. Hal ini diperoleh dari hasil keterangan wawancara kepala Unit UPT Dinas Pengelolaan Keuangan dan Aset Daerah Kabupaten Serang. Beliau menjelaskan bagaimana beliau menjalankan tugas dan fungsinya sebagai Kepala Unit. Dalam wawancara yang dilakukan dengan penulis, Kepala UPT Dinas Pengelolaan Keuangan dan Aset Daerah Kabupaten Serang menjelaskan rincian tugas dan fungsinya. Dan secara garis besar sesuai dengan Peraturan Gubernur Banten No. 34 Tahun 2010 pasal 3 ayat (1) dan (2). Adapun kendala yang terjadi selama ini adalah kendala waktu dalam pelaporan dan kendala dalam pemungutan pajak dan retribusi daerah. Kendala waktu yang dimaksud adalah pelaporan yang selama ini dilakukan masih cenderung terlama dan tidak sesuai dengan tanggal deadline pelaporan. Kendala dalam pemungutan pajak dan retribusi daerah Serang sering terjadi dikarenakan masih terdapat banyak pengusaha-pengusaha daerah yang tidak membayar atau membangkang dalam melaporkan dan membayar pajak dan retribusi daerah.

Selain kepala unit, sub bagian yang terdapat pada UPT Dinas Pengelolaan Keuangan dan Aset Daerah Kabupaten Serang adalah Sub Bagian Tata Usaha. Uraian tugas dan wewenang kepala unit diatur dalam Peraturan Gubernur Banten No. 34 Tahun 2010 pasal 4 ayat (1) dan (2). Berdasarkan pasal 4 ayat (1), Sub Bagian Tata Usaha mempunyai tugas melaksanakan pengumpulan bahan, koordinasi penyusunan program, evaluasi dan pelaporan serta pengelolaan keuangan dan umum yang meliputi kegiatan kepegawaian, tata naskah dinas, kearsipan, pengelolaan barang, rumah tangga dan humas serta 
perjalanan dinas. Sedangkan fungsi sub Bagian Tata Usaha menurut pasal 4 ayat (2) adalah:

a. penyiapan bahan, pengolahan data dan penyusunan rencana kegiatan dibidangnya;

b. pengumpulan bahan dan koordinasi, pengolahan data penyusunan program kerja UPT;

c. penyiapan bahan administrasi dan koordinasi penyusunan pelaporan keuangan UPT;

d. penyiapan bahan pengelolaan administrasi kepegawaian UPT;

e. penyiapan bahan pengelolaan perlengkapan, tata naskah dinas, kearsipan, rumah tangga, kehumasan dan perjalanan dinas, di lingkungan UPT;

f. penyiapan bahan rencana kebutuhan, pengadaan dan pemeliharaan inventaris UPT;

g. penyiapan bahan penyusunan laporan dan evaluasi pelaksanaan program di lingkungan UPT;

h. pelaksanaan tugas lain yang diberikan oleh Kepala UPT.

Dalam pelaksanaannya, sub bagian tata usaha UPT Dinas Pengelolaan Keuangan dan Aset Daerah Kabupaten Serang telah menjalankan tata kerja sesuai dengan Pergub Banten No. 34 pasal 4 ayat (1) dan (2). Hal tersebut dapat disimpulkan dari hasil wawancara dengan Kepala sub bagian tata usaha. Kepala sub bagian tata usaha UPT Dinas Pengelolaan Keuangan dan Aset Daerah Kabupaten Serang menjelaskan bagaimana alur kerja dan pelaksanaan tugas dan fungsi pegawai sub bagian tata usaha. Berdasarkan hasil wawancara dapat disimpulkan alur kerja sub bagian tata usaha sudah sesuai dengan alur kerja dan tata kerja Pergub Banten No. 34 pasal 4 ayat (1) dan (2). Akan tetapi dalam pelaksanaannya masih terdapat beberapa kendala dan kekurangan, dimana masih ada pegawai yang belum melakukan kearsipan dengan baik sehingga ketika membutuhkan dokumen lama masih harus mencari dengan waktu yang cukup lama.
Bagian lain yang terdapat dalam UPT Dinas Pengelolaan Keuangan dan Aset Daerah Kabupaten Serang adalah Seksi PKB dan BBNKB. Uraian tugas dan wewenang kepala unit diatur dalam Peraturan Gubernur Banten No. 34 Tahun 2010 pasal 5 ayat (1) dan (2). Menurut pasal 5 ayat (1) Seksi PKB dan BBNKB mempunyai tugas melaksanakan penyiapan bahan koordinasi perencanaan, evaluasi dan pelaporan serta penyelenggaraan pendaftaran, pendataan, perhitungan, penetapan, penerimaan dan penagihan PKB dan BBNKB. Sedangkan menurut pasal 5 ayat (2) Dalam melaksanakan tugas sebagaimana dimaksud pada ayat (1), Seksi PKB dan BBNKB mempunyai fungsi :

a. penyiapan bahan, pengolahan data dan penyusunan rencana kegiatan dibidangnya;

b. penyiapan bahan penyusunan laporan dan evaluasi pelaksanaan program dibidangnya;

c. pelaksanaan tugas lain yang diberikan oleh Kepala UPT.

Berdasarkan hasil wawancara dengan salah satu staf di Seksi PKB dan BBNKB UPT Dinas Pengelolaan Keuangan dan Aset Daerah Kabupaten Serang dapat diketahui bahwa tata kerja dan SOP yang berlaku di seksi PKB sudah sesuai dengan pedoman kerja yang didasarkan pada Peraturan Gubernur Banten No. 34 Tahun 2010 pasal 5 ayat (1) dan (2). Kendala yang dihadapi adalah masih banyaknya warga Serang yang tidak menyetorkan PKB sehingga pendapatan pemerintah Daerah Serang dari PKB masih cenderung belum maksimal.

Bagian terakhir yang terdapat dalam UPT Dinas Pengelolaan Keuangan dan Aset Daerah Kabupaten Serang adalah Seksi Pendapatan Lain-lain. Uraian tugas dan wewenang kepala unit diatur dalam Peraturan Gubernur Banten No. 34 Tahun 2010 pasal 6 ayat (1) dan (2). Dalam pasal 6 ayat (1) dijelaskan bahwa Seksi Pendapatan Lain-lain mempunyai tugas melaksanakan penyiapan bahan koordinasi perencanaan, evaluasi dan pelaporan serta penyelenggaraan pendaftaran, 
pendataan, perhitungan, penetapan, penerimaan dan penagihan Pajak Daerah Non PKB dan BBNKB. Sedangkan pada pasal 6 ayat (2) dijelaskan bahwa dalam melaksanakan tugas sebagaimana dimaksud pada ayat (1), Seksi Pendapatan Lain-lain mempunyai fungsi :

a. penyiapan bahan, pengolahan data dan penyusunan rencana kegiatan dibidangnya;

b. pelaksanaan tugas lain yang diberikan oleh Kepala UPT.

Berdasarkan hasil wawancara dengan salah satu staf di Seksi Pendapatan lain-lain UPT Dinas Pengelolaan Keuangan dan Aset Daerah Kabupaten Serang dapat diketahui bahwa tata kerja dan SOP yang berlaku sudah sesuai dengan pedoman kerja yang didasarkan pada Peraturan Gubernur Banten No. 34 Tahun 2010 pasal 6 ayat (1) dan (2). Kendala yang dihadapi adalah masih banyaknya warga Serang yang tidak menyetorkan Non PKB dan BBNKB sehingga pendapatan pemerintah Daerah Serang dari Non PKB dan BBNKB masih cenderung belum maksimal.

Berdasarkan hasil wawancara dengan Kepala Unit, Kepala Sub Bagian Tata Usaha, staf PKB dan BBNKB serta staf Pendapatan lain-lain dapat disimpulkan bahwa kebijakan publik yakni Peraturan Gubernur No. 34 Tahun 2010 tentang Uraian Tugas dan Fungsi Unit Pelaksana Teknis Dinas pada Daerah Provinsi Banten sudah dijalankan oleh UPT Dinas Pengelolaan Keuangan dan Aset Daerah Kabupaten Serang dengan baik. Organisasi UPT Dinas Pengelolaan Keuangan dan Aset Daerah Kabupaten Serang menjalankan setiap pekerjaan, tugas dan fungsi mereka dengan berpedoman pada Pergub Banten . 34 Tahun 2010. Ketertiban UPT Dinas Pengelolaan Keuangan dan Aset Daerah Kabupaten Serang dalam menjalankan kebijakan publik berdampak pada berjalannya kegiatan organiasi secara efektif. Setiap bagian dari organisasi telah memiliki peran dan fungsi masing-masing dan dijalankan dengan baik dan bekerja dalam satu garis komando.

Pentingnya sebuah struktur organisasi akan membantu manajer dari hasil keputusan dalam mendesain organisasi sebagai cara mengidentifikasi dari pengelolaan sumber daya manusia dan segala fungsi-fungsi yang ada untuk penyelesaian pekerjaan perusahaan dengan pedoman visi, misi dan tujuan organisasi (Gammahendra dkk, 2014:3). Struktur dan tata kerja yang dibangun dari Pergub Banten . 34 Tahun 2010 telah berdampak pada efektvitas organisasi UPT Dinas Pengelolaan Keuangan dan Aset Daerah Kabupaten hal ini dapat dilihat bahwa kendala yang muncul dari sisi internal dan kinerja cenderung sedikit dan dapat dilakukan evaluasi untuk mengatasinya.

Berdasarkan data yang diperoleh yang dapat menggambarkan bahwa uraian tugas dan fungsi Unit Pelaksana Teknis Dinas pada Daerah Provinsi Banten sudah dijalankan oleh UPT Dinas Pengelolaan Keuangan dan Aset Daerah Kabupaten Serang dengan baik dari Dinas Pengelolaan Keuangan dan Aset Daerah Kabupaten Serang, digambarkan dengan kemandirian keuangan daerah Kabupaten Serang selama periode 2011-2016.

\section{Tabel 1.1}

Laporan Realisasi Penerimaan Kabupaten Serang Berdasarkan Jenis Pendapatan periode 2011-2016 (dalam rupiah)

\begin{tabular}{|c|c|c|c|c|}
\hline Tahum & $\begin{array}{l}\text { Pendopatan } \\
\text { Asli Daurath } \\
\text { (PAD) }\end{array}$ & $\begin{array}{c}\text { Dans } \\
\text { Perimbangan }\end{array}$ & $\begin{array}{c}\text { Lain-Tain } \\
\text { Peadapatan } \\
\text { Dourah Yang Sal }\end{array}$ & $\begin{array}{c}\text { Total } \\
\text { Peserimaan }\end{array}$ \\
\hline 2011 & 216.956 .155 .419 & $773.980 .962 .44 t$ & 331.492 .556 .011 & 1322.429 .273 .871 \\
\hline 2012 & 256.582 .038 .963 & 945357974.991 & 274.429 .386 .213 & 1.476 .369 .400 .15 \\
\hline 2013 & 371.597.552.721 & 1.008 .059 .543 .000 & 322.065 .005 .259 & 1.731 .722 .100 .980 \\
\hline 2014 & 464.326 .280 .000 & 1.108 843.869 .000 & 438.898.168.090 & 2012.065.317.00 \\
\hline 2019 & 579.605 .446 .965 & 1.114 .450 .170 .958 & 610.752 .123 .586 & 2.04 .537 .741 .505 \\
\hline 2016 & 590.870 .466 .125 & 1419.934 .466 .039 & 497.672 .363 .190 & $2+465077.495 .35$ \\
\hline
\end{tabular}

Sumber : Dinas Pengelolaan Keuangan dan Aset Daerah Kabupaten Serang

Pada tabel diatas dapat dilihat bahwa kontribusi PAD terhadap Penerimaan Daerah Kabupaten masih sangat rendah dibandingkan sumber pendapatan yang lainnya seperti Dana Perimbangan dan Lain dilihat besarnya Dana Perimbangan mmasih mendominasi Penerimaan Daerah dibandingkan dengan Pendapatan Asli Daerah (PAD). Hal tersebut mengindikasikan masih rendahnya kemandirian akibat tingginya ketergantungan fiskal pemerintah Kabupaten Serang terhadap 
pemerintah pusat selama kurun waktu 20112016. Keberhasilan suatu daerah dalam menjalankan otonomi daerah ditunjukan dengan ketergantungan kepada bantuan pusat harus seminimal mungkin, agar pendapatan asli daerah (PAD) dapat menjadi bagian sumber keuangan terbesar sehingga peranan pemerintah daerah menjadi lebih besar.

\section{KESIMPULAN}

Peneltian ini menyimpulkan bahwa Implementasi kebiajkan yakni Peraturan Gubernur No. 34 Tahun 2010 tentang Uraian Tugas dan Fungsi Unit Pelaksana Teknis Dinas pada Daerah Provinsi Banten sudah dijalankan oleh UPT Dinas Pengelolaan Keuangan dan Aset Daerah Kabupaten Serang dengan baik. Ketertiban UPT Dinas Pengelolaan Keuangan dan Aset Daerah Kabupaten Serang dalam menjalankan kebijakan publik berdampak pada berjalannya kegiatan organiasi secara efektif. Setiap bagian dari organisasi telah memiliki peran dan fungsi masing-masing dan dijalankan dengan baik dan bekerja dalam satu garis komando. Struktur dan tata kerja yang dibangun dari Pergub Banten . 34 Tahun 2010 telah berdampak pada efektvitas organisasi UPT Dinas Pengelolaan Keuangan dan Aset Daerah Kabupaten hal ini dapat dilihat bahwa kendala yang muncul dari sisi internal dan kinerja cenderung sedikit dan dapat dilakukan evaluasi untuk mengatasinya.

\section{DAFTAR PUSTAKA}

Abidin, Said Zainal. 2004. Kebijakan Publik. Penerbit Pancur SiwahAmal, Ichlasul Jakarta.

Abidin, Zainal Said. 2006. Kebijakan Publik. Suara Bebas, Jakarta.

Abdul Wahab, Solikin, 2001. Analisis Kebijakan Dari Formulasi KeImplementasi Kebijakan Negara, Bumi Aksara, Jakarta

Adi Sutanto, 2003. Kewiraswastaan. Ghalia Indonesia Dan Umm Press, Jakarta.
Agustino, Leo. 2012. Dasar-Dasar Kebijakan Publik. Cetakan Ketiga. ALFABETA, Bandung.

Arikunto, Suharsimi, 2002. Prosedur Penelitian Suatu Pendekatan Praktek. Rineka Cipta, Jakarta.

Dwidjowijoto, Nugroho, Riant. 2006. Kebijakan Publik Untuk Negara-Negara Berkembang. PT. Elex Media Komputindo, Gramedia, Jakarta.

Fermana, Surya. 2009. Kebijakan Publik Sebuah Tinjauan Filosofi, Media Group Jogjakarta.

Hessel Nogi S. Tangkilisan, 2003 "Teori dan Konsep Kebijakan Publik" dalam Kebijakan Publik yang Membumi, konsep, strategi dan kasus, Lukman Offset dan YPAPI, Yogyakarta.

Islami, Irfan. 2003. Prinsip-prinsip perumusan Kebijakan Negara, Bumi Aksar, Jakarta.

J. Meleong, Lexy. 2008. Metode Penelitian Kualitatif. PT Remaja Rosdikarya. Jakarta.

Sarwono, Jonathan. 2006. Metode Penelitian Kuantitatif dan Kualitatif Edisi Pertama, Graha Ilmu Yogyakarta.

Gammahendra, Fianda., Djamhur Hamid, dan Muhammad Faisal Riza. 2014. "Pengaruh Struktur Organisasi terhadap Efektivitas Organisasi (Studi Pada Persepsi Pegawai Tetap Kantor Perwakilan Bank Indonesia Kediri). Jurnal Administrasi Bisnis (JAB)| Vol. 7 No. 2 Januari 2014

Rahmat, Pupu Saeful. 2009. Penelitian Kualitatif. Equilibrium Vol 5 No 9 Januari-Juni 2009 Hal 1-8 
Peraturan Daerah Provinsi Banten Nomor 3 Tahun 2008 tentang Pembentukan, Organisasi dan Tata Kerja Dinas Daerah Provinsi Banten.

Peraturan Gubernur No. 34 Tahun 2010 tentang Uraian Tugas dan Fungsi Unit Pelaksana Teknis Dinas pada Daerah Provinsi Banten

Undang-Undang (UU) Nomor 22 Tahun 1999 tentang Pemerintahan Daerah

UU No 32 tahun 2004 tentang Pemerintahan Daerah. 